\title{
On Jhering's passive Wirkungen and the proprietary effect of the fulfilment of the condition in case of a transfer subject to a suspensive condition
}

\section{Introduction}

Suppose A transfers assets to B but under a suspensive condition. Shortly afterwards, A transfers the assets yet again, but now to $\mathrm{C}$. Thereupon, the suspensive condition is fulfilled. Will $\mathrm{B}$ become the owner of the assets, at the expense of $\mathrm{C}$ ?

In Dutch legal literature, it is widely assumed that if the condition is met, B will become owner by operation of law. ${ }^{1}$ The subsequent transfer to $\mathrm{C}$ will not interfere with the acquisition of the assets by B if the condition is fulfilled. This effect under property law is referred to as the proprietary effect of the fulfilment of the condition. Although there is a widespread consensus in Dutch legal literature that the fulfilment of a condition in the case of a transfer of ownership subject to a suspensive condition has proprietary effect, there is, however, no consensus on how such an effect should be explained within the legal system.

German scholar Jhering has elaborated on how to explain that B will become owner if the condition is met, even at the expense of C. In his article 'Passive Wirkungen der Rechte', he creates a theory based on Roman law in which the expectations of B as the future owner under suspensive condition, are protected by the 'legal bond' of the assets, by in his words 'die Gebundenheit der Sache'. ${ }^{2}$ When A transfers assets to B under a suspensive condition, these assets are 'legally bound' to the disposition in the sense that B will acquire the ownership upon the fulfilment of the condition. Dispositions A executes pending the condition will not prevent $\mathrm{B}$ from acquiring the assets if the condition is fulfilled. As this article aims to illustrate, Jhering's doctrine offers an explanation for the proprietary effect of the transfer under a suspensive condition which may still be a contribution to Dutch legal doctrine.

1 In Dutch law, a third party in good faith, can become owner after all via third-party protection (art. 3:86 BW for movable and art. 3:88 BW for immovable goods). Further protection may be possible via art. 3:36 BW.

2 Jhering's article 'Passive Wirkungen der Rechte' appeared in 1871 in his 'Jahrbücher für die Dogmatik des heutigen römischen und deutschen Privatrechts'. See Jhering, 'Passive Wirkungen der Rechte', Jahrbücher für die Dogmatik des heutigen römischen und deutschen Privatrechts, Bd 10 1871, p. 387-586. This article was reprinted in Gesammelte Aufsätze aus den Jahrbüchern für die Dogmatik des heutigen römischen und deutschen Privatrecht, part II, Jena: Gustav Fischer 1882. This article will hereafter be referenced as Jhering 1871. 


\section{REEHUIS}

\section{Passive Wirkungen}

Traditionally, the proprietary effect of the fulfilment of the suspensive condition was explained through the retroactive effect. ${ }^{3}$ With regard to the ius commune, various legal scholars have used retroactivity to conclude that B becomes owner at the expense of C. ${ }^{4}$ Once the condition was met, one assumed that $\mathrm{B}$ had been owner from the moment the assets were transferred, because of the retroactive effect of the fulfilment of the suspensive condition under which the assets were transferred by A to B. ${ }^{5}$ In retrospect, $\mathrm{C}-$ who thought he was the owner because of the transfer - had never been the owner since A was considered not to have been the owner anymore when he transferred the assets to C. In the nineteenth century, several writers wondered whether the fulfilment of the condition did indeed have a retroactive effect. ${ }^{6}$ Jhering criticised the application of retroactivity in the case of a conditional transfer. It is an 'odd force' that is unnecessary and 'turns everything upside down'. ${ }^{7}$ But how does Jhering explain the proprietary effect without using retroactive effect? How does B, at the expense of $\mathrm{C}$, become owner if the condition is met?

Jhering assumes that when executing a transfer under a suspensive condition, the assets are 'legally bound' so that they will become property of B after the fulfilment of the condition. Because of the 'legal bond' of the assets - Gebundenheit der Sache - later dispositions by A have no influence on the obtaining of the ownership by the future owner under suspensive condition. This is an application of his theory of 'passive Wirkungen's. He published this doctrine in an almost 200 pages long article titled 'Passive Wirkungen der Rechte'. It appeared in 1871 in his 'Jahrbücher für die Dogmatik des heutigen römischen und deutschen Privatrechts'. What is Jhering's theory of 'passive Wirkungen der Rechte' in short?

3 The retroactive effect of the fulfilment of the condition existed as dogma for a long time. According to Schiemann, it was Bartolus who shaped the idea: 'conditio in contractibus trahitur retro'. For the development of the dogma of the retroactive effect, see Schiemann, Pendenz und Rückwirkung der Bedingung. Eine dogmengeschichtliche Untersuchung, Köln Wien: Böhlau-Verlag 1973.

4 See, for instance, Sell, Über bedingte Traditionen zugleich als Revision der Lehre von den Wirkungen der Bedingungen bei Verträgen im Allgemeinen: eine civilistische Erörterung, Zürich: Meyer u. Zeller 1839, p. 105; In Sell's footsteps follows Savigny, System des heutigen Römischen Rechts. Bd. 3, Berlin: Veit and Comp. 1840 p. 150-151; See also Pothier, Traité des obligations, Paris: Debure l'ainé 1761 p. 249 or no. 220.

5 'Dass die Verfügungen, welche der Tradent pendente conditione über die Sache getroffen hat, jetzt definitiv als ungültig erscheinen, und zwar rückwärts von Anfang an; sowie jetzt umgekehrt die Dispositionen des Empfängers Gültigkeit erlangen können. [...]' according to Sell, Über bedingte Traditionen zugleich als Revision der Lehre von den Wirkungen der Bedingungen bei Verträgen im Allgemeinen: eine civilistische Erörterung, Zürich: Meyer u. Zeller 1839 p.157.

6 The start was given by Windscheid in Die Wirkung der erfüllten Bedingung: eine akademische Gelegenheitsschrift, Basel: Schweighauser 1851. After that came Fitting, Über den Begriff der Rückziehung, Erlangen: Andreas Deichert 1856; Vangerow, Lehrbuch der Pandekten, Erster Band, Marburg and Leipzig: R. G. Elwertsche Universitätsbuchhandlung 1863, p. $141 \mathrm{ff}$.

$7 \quad$ Jhering 1871, p. 527-528. See also p. 402-403, 534-535 and 538.

$8 \quad$ Jhering 1871 , p. 387-586. 


\section{ON JHERING'S PASSIVE WIRKUNGEN}

The starting point of Jhering's theory of the 'passive Wirkungen' is that a right which is granted to a legal subject by private law has two aspects. On the one hand, the legal subject derives a legal status from the granted right consisting of powers that correspond with the purpose of the right. ${ }^{9}$ For instance, a pledge granted to a legal subject makes him a pledgee, from which he will derive the power to execute the pledged object if the debt for which the pledge gives security is not paid off. Jhering describes this as the active side of the right. He calls the powers of this right for the entitled person 'active Wirkungen'. However, not only does the right operate from the point of view of the person entitled to it, the right's existence also implies that another person or an asset is subjected to the purpose of that right. ${ }^{10}$ After all, a pledge cannot exist without a corresponding legal object, the pledged object. Similarly, an obligation without a debtor is not possible. Jhering calls this relationship between the purpose of the right and the person or assets, the passive side of the right. The effects that arise from this relationship are passive effects or 'passive Wirkungen'.

In other words, the existence of the right's passive side is a consequence of the existence of the right's active side. According to Jhering, however, the existence of the passive side does not always imply the existence of the active side. He notes that in Roman law, legal relationships with just a passive side exist, without there being an active right for a legal subject. This is the case, amongst others, in the preliminary stages of the creation or the transition of a right. ${ }^{11}$ Jhering gives as the example of a slave who is released under a suspensive condition. Although, pending the condition, the slave is not (yet) free, no one will be able to prevent him from getting his freedom if the suspensive condition is met (see 2.2.1). ${ }^{12} \mathrm{At}$ first sight, it seems illogical that there are legal effects without a corresponding right. Jhering does not consider this problematic, emphasising the relationship between means and purpose instead of the relationship between cause and effect. ${ }^{13}$ If the purpose is to obtain a right if a suspensive condition is met, the means are preceding that purpose to serve and protect that acquisition if the condition is fulfilled. The instrument to achieve this purpose is the

$9 \quad$ Jhering 1871, p. 392 ff.

10 Personality rights are an exception for Jhering.

11 He distinguishes two categories in which these passive Wirkungen appear. First, in cases where the legal object is temporarily absent. An example is the opening of a succession, where the beneficiary has not yet accepted the inheritance. This inheritance, which has not yet been accepted, the hereditas jacens, is not a legal subject until the acceptance and precludes the existence of an active right. Even so, the inheritance is bound so that the heir actually does become owner upon acceptance. There are also already passive Wirkungen that ensure that the heir really does become owner when he accepts the inheritance. That means that Jhering does not have to assume the fiction - used by other writers - that the hereditas jacens has a juridical person. Jhering discussed the hereditas jacens on p. 406. Second, according to Jhering, the passive Wirkungen appear in the preliminary stages of the beginning or the transition of a right. One case where this happens is discussed in this article, in which a transfer under suspensive condition is completed. Jhering 1871, p. 458-580.

12 Jhering 1871, p. 395-396 and p. 496 ff.

13 Jhering 1871, p. 458. For criticism see e.g.: Enneccerus, Rechtsgeschäft, Bedingung und Anfangstermin II, 1889, p. 413; Blomeyer, Studien zur Bedingungslehre I, 1938, p. 7 ff.; Schiemann, Pendenz und Rückwirkung der Bedingung. Eine dogmengeschichtliche Untersuchung, Köln Wien: Böhlau-Verlag 1973, p. 96 ff. 


\section{REEHUIS}

'legal bond' of the object. ${ }^{14}$ The passive effects (or 'passive Wirkungen') of the 'legal bond' of the person or object, protect the future owner so that he will acquire the right if the suspensive condition is met. ${ }^{15}$ In other words, the 'legal bond' of the person or object ensures that the future owner under suspensive condition will acquire the right if the condition is met. It seems, as Jhering metaphorically says:

'[...] das dem künftig Berechtigten das Bett des Rechts [...] bereits im Voraus [ist] aufgeschlagen. [...]

Das Bett ist freilich zur Zeit noch leer, aber es ist bereits belegt, dem Unberechtigten verschlossen. ${ }^{16}$

One can distinguish between the situation in which a person is 'legally bound' (nr. 2.1) and the situation in which an asset is 'legally bound' (nr. 2.2).

\subsection{The 'legal bond' of a person pending the suspensive condition}

Suppose A stipulates that he will give B a sum of money under the suspensive condition that $\mathrm{B}$ renders a service. In Roman law, a stipulation under a suspensive condition does not immediately create a debt, but only if the condition is met. ${ }^{17}$ Pending the suspensive condition, $\mathrm{B}$ cannot take action against $\mathrm{A}$ to force him to hand over the money. ${ }^{18} \mathrm{~B}$ merely has an expectation of a claim. ${ }^{19}$ Although $\mathrm{B}$ only has an expectation, there are already 'passive

14 'Wenn nämlich [...] diese Gebundenheit in nichts Anderem besteht, als in der gesetzlichen Anerkennung des Bestimmungsverhältnisses einer Person oder Sache für die mittelst des Rechts zu verfolgenden Zwecke des Berechtigten (Rechtszweck), diese Anerkennung aber, indem sie diese Person oder Sache positiv dem Berechtigten zuweist, sie damit negativ allen nicht berechtigten Personen verschließt, so begründet die Statuierung eines solchen Bestimmungsverhältnisses zu Gunsten einer künftigen Person für das betreffende Rechtsobject (Person oder Sache) schon jetzt ganz dieselbe Gebundenheit, wie der Rechtszweck des demnächstigen Rechts sie erheischt.' Jhering 1871, p. 395. See p. 462 ff. for an elaborate discussion about the 'legal bond' of the person and p. $472 \mathrm{ff}$. about the 'legal bond' of the object.

15 'Da aber, wie oft bemerkt, die Gestaltung der Rechte wesentlich durch den Zweckbegriff beeinflusst wird, so liegt nicht der geringste Widerspruch darin, dass zu Gunsten eines in der Entstehung begriffenen Rechts, also um eines künftigen Zweckens willen schon jetzt Beschränkungen Platz greifen, welche dessen künftige Verwirklichung vorbereiten und sicher stellen sollen. Zeigt es sich nun, dass diese SchutzMaßregeln gerade in denselben beschränkenden Wirkungen bestehen, durch welche das vorhandene Recht seine Existenz nach außen hin bethätigt, so werden wir berechtigt sein, das Verhältnisz, um das es sich hierbei handelt, als Eintritt der passiven Wirkungen des Rechts vor den activen zu bezeichnen.' Jhering 1871, p. 458.

16 Jhering 1871, p. 395.

17 See D. 50,16,54 which shows that 'contingent creditors' can also be those who do not yet have, but are expectant of, an action. And D. 50,16,213 in which is mentioned that the debt only comes into being at the fulfilment of the condition.

18 Jhering 1871, p. 463; Jhering, Geist des römischen Rechts III-I, Leipzig: 1865 Breitkopf and Härtel p. 160 ff.; Van Oven, Leerboek van romeinsch privaatrecht, Leiden: E.J. Brill 1948, p. 393; Ankum, 'De opschortende voorwaarde naar Romeins recht en volgens het Nederlandse Burgerlijk Wetboek', $B W$ krant Jaarboek 1994, p. 27-30.

19 See, for instance, 'ex condicionali stipulatione tantum spes est debitum iri' in Institutes 3,15,4. See also D. 50,16,54 and D. 50,16,213. 


\section{ON JHERING'S PASSIVE WIRKUNGEN}

Wirkungen' that ensure his entitlement to the claim if the suspensive condition is met. It follows from, amongst others, D. 35,1,24, D. 50,17,161 and D. 45,1,85,7 that if the debtor prevents the condition from being met, the condition will have to be regarded as fulfilled. If A prevents the fulfilment of the condition, it should be considered as met. Pending the condition, A is already 'legally bound' not to frustrate the condition's fulfilment, and thus, the emergence of the obligation. B does not have a right pending the condition, but his expectation is protected by the 'legal bond' of A. Jhering calls that an 'in der Bildung begriffene Obligation'. ${ }^{20}$ Jhering describes this as follows:

'Indem das Recht eine derartige Vereitlung der Bedingung der Erfüllung derselben gleichstellt, beabsichtigt es damit, den Promittenten von solchen störenden Eingriffen abzuhalten, es beschränkt seine Freiheit, es bindet ihn. Wir haben hier demnach das, was wir suchen: eine Gebundenheit des Schuldners vor Entstehung der Forderung, den Eintritt gewisser passiven Wirkungen des Rechtsverhältnisses den activen, berechnet darauf, die Entstehung des Rechts zu sichern.'21

Jhering compares the protected expectation of B to the legal position of an unborn child (nasciturus). ${ }^{22}$ As a legal subject to be, a foetus does not have any rights (yet), but his interests are already protected. ${ }^{23}$ This also applies to a conditional creditor. He does not have a right to claim (yet), but the process of the potentially coming into being of the right to claim is protected by the 'legal bond' of the suspensive debtor.

\subsection{The 'legal bond' of assets pending the suspensive condition}

When an obligation is contracted under a suspensive condition, the claim will come into existence only if the suspensive condition is met. Although, pending the condition, there is no right to claim (yet), there is already a legal relationship according to which the debtor as a person is 'legally bound' not to frustrate the fulfilment of the condition and, thus, the existence of the obligation. The 'legal bond' of the debtor protects the creditor's expectation

20 See: Jhering 1871, p. $462 \mathrm{ff}$.

21 Jhering 1871 , p. 464

22 'Denn während die betagte Obligation bereits sofort zur Existenz gelangt, und der Tag nur ihre Erfüllung hinausschiebt, befindet sich die bedingte bis zum Eintritt der Bedingung in dem Zustand des Werdens, der Bildung - ein Zustand, den das Recht (ich möchte fast sagen: ähnlich wie beim nasciturus!) durch das Verbot aller störende Eingriffe in den ruhigen Verlauf des Entwicklungsprocesses in Schutz nimmt.' Jhering, Geist des römischen Rechts III-I, Leipzig: 1865 Breitkopf und Härtel p. 160.

23 An unborn child is considered born if it is in its interest, for instance to act as an heir. The often-used saying 'nasciturus pro iam nato habetur' does not appear literally in the sources, but follows from D. 1,5,7 and D 1,5,26. About Roman law, see Kaser, Das römische Privatrecht. Erster Abschnitt: Das altrömische, das vorklassische und klassische Recht, München: C.H. Beck'sche Verlagsbuchhandlung 1971, p. 272 and 289. Dutch law has a comparable provision in Art. 1:2 BW. This stipulates loosely translated: 'The child that the woman is pregnant with is regarded to have been born already, if its interests require so. If it is stillborn, it is deemed to have never existed.' 


\section{REEHUIS}

with regard to his right to claim coming into existence should the condition be fulfilled. According to Jhering, this 'legal bond' that precedes the condition's fulfilment, also exists in the case of conditional proprietary dispositions, but then in the form of a 'legal bond' of the asset:

'Wie dort der Forderung des Gläubigers eine Gebundenheit des Schuldners, so kann hier dem Eigenthum oder jus in re eine Gebundenheit der Sache vorangehen, vermöge deren sie, wie positiv dem zukünftigen Berechtigten zugesichert, so negativ allen andern verschlossen ist. ${ }^{24}$

Several texts in Roman sources support the assumption that an asset is 'legally bound' by the disposition that is carried out under a condition. ${ }^{25}$ The doctrine of the slave released under a suspensive condition is the oldest form in which the 'legal bond' of the asset appears in Roman law.

\subsubsection{The conditional release of slaves}

In Roman law, it was possible for slaves to be released under a suspensive condition. When the release by will occurred under a suspensive condition, the slave in question was called a statuliber ${ }^{26}$ Suppose A released a slave under a suspensive condition in his will and named $B$ as his sole heir. What was the legal position of the slave pending the suspensive condition when A died? And what was the legal position of heir B with regard to the slave?

Ulpian says the 'statuliber is the slave of the heir for as long as the condition is unfulfilled'. ${ }^{27}$ The implication of a conditional release is that the slave, pending the suspensive condition, is not free (yet), but belongs to the heir. ${ }^{28}$ The slave will only obtain his freedom if the suspensive condition is fulfilled. Until that moment, he only has an expectation of freedom, much like the conditional creditor only has an expectation of the claim. The expectation of freedom is indicated in the Roman sources as spes or specifically as spes libertatis. ${ }^{29}$

So in Roman law, although the slave was not free (yet), his expectation of freedom was protected. The basic principle of this protection was that his expectation of being released if the condition was fulfilled could not be frustrated..$^{30}$ The heir and owner B should not

\footnotetext{
24 Jhering 1871, p. 472.

25 Jhering notices this, amongst others, in the Roman Law legatum optionis; see Jhering 1871, p. 481 ff. He also finds such a legal commitment of assets in the former German law; for instance, in the German Grundbuchliche Vormerkung p. 488 ff. For many other examples, see p. 472-580.

26 Ulpian, Rules 2,1: 'A slave, whose release by testament is ordered under condition, is called "statuliber"'. See also D. 40,7,2.

27 Ulpian, Rules 2,2.

28 See also D 40,7,9 pr and D 40,9,29,1.

29 See D 40,7,9,2 pr.; 40,7,9,3 and D 48,18,8,1. Also, the enslaved person, as a legal object, cannot yet have a right. He only becomes a legal subject when the condition is met.

30 D 40,7,33.
} 


\section{ON JHERING'S PASSIVE WIRKUNGEN}

frustrate the condition's fulfilment. ${ }^{31}$

But what happened if $\mathrm{B}$, pending the fulfilment of the condition, disposed of the slave by, for instance, selling and transferring him to a third person, C ${ }^{32}$ Would the transfer of the slave to $\mathrm{C}$ frustrate the release of the slave if the condition was fulfilled? The answer is no. If the conditionally released slave was transferred to $\mathrm{C}, \mathrm{C}$ would be the owner for as long as the condition was not met. Nevertheless, the slave would be free if the condition was fulfilled eventually, according to D 40,7,2 pr.:

'He, who has the status of being conditionally released, finds himself in the following situation: if he is transferred, he will be disposed of while retaining the expectation of his freedom $[\ldots]^{33}$

The expectation of freedom was, metaphorically speaking, a seed from which the right - his freedom - would inevitably grow if the condition was met. ${ }^{34}$ Consequently, the heir could only dispose of the slave in accordance with this expectation. ${ }^{35}$ This is an example of a situation in which the owner's power of disposition was limited by the 'legal bond' of the asset preceding the fulfilment of the condition. Jhering describes the position of the conditionally released slave as follows:

'Der Statuliber steht im Eigentum des Erben, aber dasselbe ist beschränkt durch die ihm verliehene Aussicht auf Freiheit, er trägt diese Hoffnung überall mit sich. ${ }^{36}$

Through this 'legal bond', the slave is protected against the dispositions the heir carries out pending the suspensive condition, yet without the slave being granted an active right.

The case of the conditionally released slave is peculiar. It concerns a special case in which a legal object can become a legal subject if the condition is fulfilled. Therefore, as long as

31 In the Digests, book 40 title 9 about the statuliber, there are many texts with case studies in which the central question is whether the slave obtains his freedom because the heir frustrates the fulfilment of the condition to such an extent that the condition has to be considered fulfilled already. For instance, if the condition prescribes that the slave has to pay the heir a sum of money and the heir refuses to accept the money, then the slave obtains his freedom (D. 40,7,3,1). See, amongst others, also Ulpian, Rules 2,5; D. $40,7,3$; D. 40,7,3,3; D. 40,7,3,4; D. 40,7,3,7; D. 40,7,3,8; D. 40,7,3,3; D. 40,7,3,16 and D. 40,7,4,3.

32 See for an example D. 40,7,25.

33 See also Ulpian, Rules 2,3. See Fitting, Über den Begriff der Rückziehung, Erlangen: Andreas Deichert 1856, p. 69 ff.; Jhering 1871, p. 498.

34 Jhering describes this as follows: 'ein Keim, aus dem mit Eintritt der Bedingung das Recht selber: die Freiheit unabwendlich hervorgeht.', Jhering 1871, p. 396. See also Fitting, Über den Begriff der Rückziehung, Erlangen: Andreas Deichert 1856 p. 65.

35 In Title 7 of book 40 of the Digests, there are many elaborations of this starting point. For instance, D. $40,7,9,1$; D. 40,7,25 and D. 40,7,35. But also D. 48,18,8,1.

36 Jhering continues: 'Das Interesse diese Verhältnisses für unsern Gesichtspunkt der passiven Gebundenheit ist bereits oben hervorgehoben worden, der statuliber ist das älteste nachweisbare Beispiel des rechtlichen Schutzes eines in der Entstehung begriffenen Rechts in Form der Gebundenheit der Sache zugleich der erste Fall eines durch ein künftiges Recht dinglich beschränkten Eigenthums', Jhering 1871, p. 498. 


\section{REEHUIS}

the condition is unfulfilled, he cannot have any right. The outcome might be different if a conditional transfer of rights between two already existing legal subjects takes place, such as a conditional bequest per vindicationem.${ }^{37}$ One might assume that pending the condition, the recipient of the bequest has already acquired a (conditional) right. However, it were the Roman jurists themselves who have been guided by what applies to the conditional release of slaves, also with regard to the conditional bequest per vindicationem.

\subsubsection{The bequest per vindicationem subject to a suspensive condition}

Consider the situation in which A names B as his sole heir in his will, but bequeaths per vindicationem an asset under a suspensive condition to $\mathrm{C}$. Who is entitled to the asset pending the condition?

Through the Institutes of Gaius, we know that the Proculians and the Sabinians held different opinions on the legal situation pending the suspensive condition. ${ }^{38}$ According to the Proculians, the asset was a res nullius pending the condition, and neither B nor C was entitled to it. The Sabinians had a different opinion. They assumed that the case of the conditionally released slave had to be taken as an example. This meant that heir B was the owner pending the condition. Recipient of the bequest $\mathrm{C}$ had no right to the conditionally bequeathed asset pending the condition, but merely an expectation of ownership. The Sabinian view had become the ruling doctrine. Jhering writes that in the Roman sources, the legacy per vindicationem under a suspensive condition is equated to the conditional release:

'beide enthielten einen Dispositionsakt des Testators über seine Sache, der mit Eintritt der Bedingung ipso jure in Wirksamkeit trat, und der eben darum durch entgegenstehende Verfügungen des Erben nicht vereitelt werden konnte. ${ }^{39}$

In our example, this means that $\mathrm{B}$, as sole heir, is owner of the asset pending the condition's fulfilment. ${ }^{40} \mathrm{He}$ can recover the asset as owner. ${ }^{41} \mathrm{He}$ is entitled to the profits of the asset. ${ }^{42}$ He can also dispose of it, ${ }^{43}$ which means he can sell, ${ }^{44}$ pledge ${ }^{45}$ and bequeath it. ${ }^{46}$

37 The bequest per vindicationem is a bequest with proprietary effect. At the death of the testator, the legatee acquires the right bequeathed to him. Kaser, Das römische Privatrecht. Erster Abschnitt: Das altrömische, das vorklassische und klassische Recht, München: C.H. Beck'sche Verlagsbuchhandlung 1971, p. 741 and further.

38 See Gaius, Institutes 2,200.

39 Jhering 1871 , p. 498. See for instance D. 10,2,12,2; D. 29,5,1,4; D. 12,14 pr; see Jhering 1871, p. 500503.

40 This follow, amongst others, from D. 10,2,12,2; D. 40,9,29,1 and D. 29,5,1,4.

41 D. $6,1,66$.

42 D. $31,32,1$; as is also the case for a conditionally released slave, D. 40,7,16.

43 See the previously mentioned D. 40,7,25 pr.

44 D. $19,1,29$.

45 D. $20,1,13,1 ;$ C. $6,43,3,3$.

46 According to D. $7,4,16$. 


\section{ON JHERING'S PASSIVE WIRKUNGEN}

Now, the question arises whether such dispositions by B frustrate the obtainment of the asset by legatee $\mathrm{C}$ if the condition is fulfilled? Despite the fact that $\mathrm{C}$ is not entitled to any right on the asset pending the condition, he - as the recipient of the conditional bequest - will be protected in his expectation of becoming owner if the condition is met. This protection is based on the idea that the expectation of legatee $\mathrm{C}$ must not be frustrated - 'ne legatario iniuria fieret' according to D. 40,9,29,1. ${ }^{47}$ Therefore, dispositions that heir B carries out pending the condition do not frustrate the expectation of the bequest's recipient that he will obtain the asset if the condition is fulfilled - 'alienam spem [non] decipere', according to C. $6,43,3,2(\mathrm{a}){ }^{48}$

If, in our example, heir B, pending the suspensive condition, transfers ownership of the asset to third party $\mathrm{D}, \mathrm{D}$ becomes entitled to the asset. If subsequently the suspensive condition is fulfilled under which the asset was bequeathed to legatee $\mathrm{C}, \mathrm{C}$ will become owner of the asset at D's expense. Dispositions that have been executed by B pending the suspensive condition will expire if the condition is fulfilled. ${ }^{49}$ After fulfilment of the condition, $\mathrm{C}$, being the owner from that moment on, can recover the asset from D, according to Gaius in D. $30,69,1$ :

'When an heir alienates a slave who was bequeathed under condition and the condition is thereafter fulfilled, the slave can nevertheless be claimed [by the recipient of the bequest]; the bequest is not extinguished. ${ }^{50}$

Hence, this is not just a binding obligation of the heir not to frustrate the expectation of the legatee of the bequest. It is a 'Nichtsanderskönnen', a proprietary impossibility, according to Jhering:

'[...] es macht die Uebertretung unmöglich, indem es die Bestimmung der Sache für den Legatar zu einer 'causa rei' $\left.{ }^{51}\right]$, einer rechtlich unzerstörlichen Eigenschaft derselber erhebt. Alle Verfügungen des Erben, welche den Anspruch des Legatars verkürzen, werden mit Eintritt der Bedingung hinfällig. ${ }^{52}$

47 D. 40,9,29,1. See also Jhering 1871 , p. $500 \mathrm{ff}$.

$48 \quad$ See Jhering 1871, p. 500.

49 The expiration does not have a retroactive effect according to Jhering. See Jhering, 1871, p. $501 \mathrm{ff}$. , in particular note 128. The following words of Digest texts indicate this: D. 8,6,11,1: 'servitutes extinguentur', which means 'expire, become ineffective'; D. 35,1,105: 'finietur'; D. 7,4,16: 'finiatur', which means 'terminate, extinguish'; D. 6,1,66 'dominium abite' which means 'He loses the ownership'; D. 20,1,13,1: 'exsistente evanescat pignus' which means 'becoming invalid, ineffective, cease to exist, extinguish'. Translation based on Heumann-Seckel, Heumanns Handlexikon Zu Den Quellen Des Romischen Rechts, Jena: Verlag von Gustav Fischer 1907.

50 D. 30.69 Gaius libro secundo de legatis ad edictum praetoris [...] 1. Si servum sub condicione legatum heres alienaverit, deinde condicio exstiterit, potest nihilo minus a legatario vindicari nec extinguitur legatum.

51 Cf. Inst. $4,17,3$.

52 Jhering 1871, p. 501. 


\section{REEHUIS}

The bequest per vindicationem under a suspensive condition does not immediately lead to the acquisition of a right by the legatee, but only if the condition is fulfilled. Pending the condition, the bequeathed asset is 'legally bound', in such a way that the recipient of the bequest will be entitled to the asset if the condition is fulfilled. This 'legal bond' of the asset limits the ownership of the heir, which makes it impossible for him to frustrate the aim of the conditional bequest per vindicationem. The expectation of the recipient of the bequest on obtaining the right is protected by the 'legal bond' of the asset against dispositions of the heir that he carries out pending the suspensive condition. Or, as Jhering writes:

'Der Erbe ist während der Zwischenzeit (von der Antretung der Erbschaft bis zum Eintritt der Bedingung) Eigenthümer, aber sein Eigenthum ist beschränkt durch die Rücksicht auf das Legat. ${ }^{53}$

How does this work when an asset is transferred subject to a suspensive condition? Does the fulfilment of the condition in the case of a conditional transfer have proprietary effect as we have seen in the situation of the conditional release and the bequest per vindicationem subject to a suspensive condition?

\subsubsection{Transfer subject to a suspensive condition}

There are only a few Roman texts about the conditional transfer. One reason for that is that it was impossible to add a condition to mancipatio and in iure cessio, the acts of transfer of the ius civile. They were formal acts which, once completed, resulted in immediate transfer of rights. ${ }^{54} \mathrm{~A}$ transfer subject to a suspensive condition was only possible in case of a transfer by traditio. ${ }^{55}$ However, the few texts on the conditional transfer by traditio do not discuss the specific question raised above either. Nevertheless, there are two texts that do discuss the effect of the fulfilment of the condition, namely D. 23,3,9,1 and D. 39,5,2,5.

In D. $23,3,9,1^{56}$ Ulpian discusses a case in which assets were delivered under the condition

53 Jhering 1871, p. 499

54 See D. 50,17,77 and Kaser, Das römische Privatrecht. Erster Abschnitt: Das altrömische, das vorklassische und klassische Recht, München: C.H. Beck'sche Verlagsbuchhandlung 1971, p. 255.

55 Traditio was made by the delivery of the asset pursuant a iusta causa, which was usually an obligation to transfer.

56 'If I deliver assets to anyone to become a dowry after marriage has taken place, and I die before the marriage is celebrated. Does the assets constitute the dowry if the marriage is afterwards performed? I am in doubt as to whether it will pass to the person to whom it is given, because he who gave it is divested of the ownership, after death, as the donation was pending until the day of the marriage; and when the condition of the marriage is fulfilled, the ownership of the assets will have already passed to the heir, and it must be held that he cannot be depried of the same without his consent. The more equitable opinion is the one in favor of the dowry (favore dotium) and for the heir to be required to consent to the act of the deceased; or, if he should defer his decision, or be absent, or be unwilling, the ownership should be transferred to the husband by operation of law, in order that the woman may not remain without a dowry.' (translation derived from Scott, The Civil Law, V, Cincinnati, 1932)

'Si res alicui tradidero, ut nuptiis secutis dotis efficiantur, et ante nuptias decessero, an secutis nuptiis dotis esse incipiant? Et vereor, ne non possint in dominio eius effici cui datae sunt, quia post mortem 


\section{ON JHERING'S PASSIVE WIRKUNGEN}

that they would become part of a dowry after the wedding had taken place. The provider of the dowry died before the wedding. The question arose as to whether the assets had become part of the dowry in spite of the death of the provider. Ulpian answered:

'I am in doubt as to whether it will pass to the person to whom it is given, because he who gave it is divested of the ownership, after death, as the donation was pending until the day of the marriage; and when the condition of the marriage is fulfilled, the ownership of the assets will have already passed to the heir, and it must be held that he cannot be deprived of the same without his consent. The more equitable opinion is the one in favor of the dowry (favore dotium) and for the heir to be required to consent to the act of the deceased; or, if he should defer his decision, or be absent, or be unwilling, the ownership should be transferred to the husband by operation of law, in order that the woman may not remain without a dowry. ${ }^{57}$

Ulpian's starting point seems to be that the delivered assets are not 'legally bound'. Had they been 'legally bound', the fulfilment of the condition would have automatically lead to the acquisition of the assets even in the event of the donor's death and without the confirmation of the heir. Neither is there a 'legal bond' of the person. Had the donor been 'legally bound', the conclusion would have been that his heir would have be bound, in the same way a conditional stipulation made by the testator binds the heir if the testator dies pending the condition. ${ }^{58}$ If so, there would have been no need for Ulpian to call on the favor dotis to come to arrive at the same result..$^{59}$

In the case of D. 39,5,2,5 by Julian, A gifts a sum of money to B under the suspensive condition that it will belong to $\mathrm{B}$ if $\mathrm{C}$ has become consul. ${ }^{60}$ Only if $\mathrm{C}$ becomes consul, $\mathrm{B}$ will obtain ownership of the sum of money. According to Julian, it does not matter if A dies or becomes mentally ill pending the condition. The fulfilment of the condition will lead to

incipiat dominium discedere ab eo qui dedit, quia pendet donatio in diem nuptiarum et cum sequitur condicio nuptiarum, iam heredis dominium est, a quo discedere rerum non posse dominium invito eo fatendum est. Sed benignius est favore dotium necessitatem imponi heredi consentire ei quod defunctus fecit aut, si distulerit vel absit, etiam nolente vel absente eo dominium ad maritum ipso iure transferri, ne mulier maneat indotata.'

57 ' [...] Et vereor, ne non possint in dominio eius effici cui datae sunt, quia post mortem incipiat dominium discedere ab eo qui dedit, quia pendet donatio in diem nuptiarum et cum sequitur condicio nuptiarum, iam heredis dominium est, a quo discedere rerum non posse dominium invito eo fatendum est. [...]'

58 See for instance D 45,1,57. In this case the possession was provided without an conditional obligation to do so. See Jhering 1871, p. 529 - 531.

59 Jhering 1871, p. $529-530$.

60 If Titius should pay me a sum of money without any stipulation, but on the condition that it will only belong to me when Seius becomes Consul, the money will become mine when Seius obtains the consulship, even though the person who made the donation should be insane or dead at that time. (translation by Scott, The Civil Law, V, Cincinnati, 1932) 'Si pecuniam mihi titius dederit absque ulla stipulatione, ea tamen condicione, ut tunc demum mea fieret, cum seius consul factus esset: sive furente eo sive mortuo seius consulatum adeptus fuerit, mea fiet.' 


\section{REEHUIS}

B becoming the owner. ${ }^{61}$ Is this a reference to the application of the doctrine of the legal bond of the asset on a transfer under suspensive condition by traditio? Jhering assumes that the asset is not 'legally bound'. He thinks that it is not likely that Julian used the concept of the 'legal bond' of the asset since nearly a hundred years later, Ulpian still believed that the favor dotis should be used to protect the conditional acquirer. Jhering thinks Julian assumed the conditional traditio 'legally bound' the donor as a person. Therefore, the 'legal bond' of donor A would lead to the acquisition of the sum of money by B if the condition was met, even if A died or became insane pending the condition. This was not the case if A transferred the assets yet again to $\mathrm{C}$. In that case, $\mathrm{C}$ remained the owner of the assets even if the condition was met. B did not become the owner. ${ }^{62}$

According to Stagl, there is a decisive difference between D. 23,3,9,1 and D. 39,5,2,5. ${ }^{63} \mathrm{In}$ D. 23,3,9,1, assets were given as a dowry, which meant that these assets would only become a dowry after the marriage had taken place ${ }^{64}$ The provision of the assets therefore had no preliminary effect because the legal act was concluded only after the marriage had taken place. This meant that the heir would not be bound if the provider of the dowry died before the marriage because there was no legal act by which he could be bound. Ulpian wished to avoid such a conclusion, but could not assume any form of a 'legal bond' because of the absence of a completed legal act. Instead, he suggested that it was a more equitable opinion to decide in favour of the dowry - favor dotis - and the result was that the assets provided for the dowry would become part of the dowry if the condition was met. ${ }^{65}$

That would mean that the Ulpian's case is different from Julian's, so that, contrary to Jhering's view, it is possible that in D. 39,5,2,5 presents an argument for the application of the 'legal bond of the asset' on the suspensive condition by traditio.

\subsubsection{Durch das römische Recht, aber über dasselbe hinaus}

Nevertheless, in Jhering's time it was desirable that the fulfilment of the condition had proprietary effect in the case of a conditional transfer of an asset. In Jhering's view, in order to achieve this, his doctrine of the 'legal bond' of the asset had to be used, as it explains the

61 Jhering 1871, p. 529-533. See also Sell, Über bedingte Traditionen zugleich als Revision der Lehre von den Wirkungen der Bedingungen bei Verträgen im Allgemeinen: eine civilistische Erörterung, Zürich: Meyer u. Zeller 1839, p. $116 \mathrm{ff}$.

62 According to Jhering, the reason why the fulfilment of the condition does not have proprietary effect when an asset is transferred conditionally by traditio, but does have proprietary effect when an asset is conditionally bequeathed, could be to respect the will of the testator after his death. In order to respect the will of the testator, one has to assume that the conditional bequest per vindicationem has proprietary effect if the condition is fulfilled, because it is not possible for the testator to postpone the disposition. For dispositions amongst people still alive, there is less need to make such an assumption. See Jhering 1871 , p. $496-498$.

63 Stagl, Favor dotis, Die Privilierung der Mitgift im System des römischen Rechts. Wien-Köln-Weimar: Böhlau 2009, p. 197- 207.

64 '[...] neque enim dos sine matrimonio esse potest.' in D 23,3,3.

65 See Stagl, Favor dotis, Die Privilierung der Mitgift im System des römischen Rechts. Wien-Köln-Weimar: Böhlau 2009, p. 203- 206. 


\section{ON JHERING'S PASSIVE WIRKUNGEN}

acquisition of the right in Roman law in the case of the conditional bequest per vindicationem and the conditional release of a slave. ${ }^{66}$ This is a clear example of how Jhering thought Roman law should be used. The 'legal bond' of the asset, which has only been expressed in some cases, should be elevated to the status of a general principle:

'Durch das römische Recht, aber über dasselbe hinaus - das ist der Wahlspruch, in dem für mich die Bedeutung des römischen Rechts für die moderne Welt beschlossen liegt. ${ }^{67}$

So, if an asset is transferred conditionally, the transfer of rights will be postponed until the moment the suspensive condition is fulfilled. It will, however, take place once the condition is met, even if the transferor alienates the asset to a third party in the meantime. In order to reach this goal, a transfer under a suspensive condition has to bind the asset immediately, so that the transferee will become the owner if the condition is fulfilled. The 'legal bond' of the asset that results from the conditional transfer limits the power of disposal, which means that any dispositions the disposer carries out pending the condition do not frustrate the acquisition of the assets if the condition is met. This limitation as a consequence of the 'legal bond' of the asset takes place, not due to an active property right, but merely to the passive Wirkungen. The transferee's expectation of becoming owner is protected by the 'legal bond' of the asset. ${ }^{6}$ Or, according to Jhering:

'Fassen wir das bisher Gesagte zusammen, so reiht sich die bedingte Tradition den vielen von uns bereits constatirten Fällen an, in denen ein in der Enstehung begriffenes Recht mittelst des Gesichtspunkts der Gebundenheit [der Sache] gegen die Gefahr der Vereitlung von Seiten des Bestellers geschützt wird. ${ }^{69}$

Can Dutch law benefit from Jhering's theory of the 'legal bond' of the assets?

66 Indeed, according to Jhering, this has already been looked at consciously or subconsciously: 'Der Gedanke einer Ausgleichung der letztwilligen und vertragsmäßigen Verfügungen in Bezug auf die Statthaftigkeit und die Wirkung der hinzugefügten Bedingung taucht schon auf dem Boden des reinen römischen rechts auf, und er ist es offenbar, der bewusst oder unbewusst der modernen Jurisprudenz bei Gestaltung der Lehre von den bedingten Traditionen vorgeschwebt hat', Jhering 1871, p. 527.

67 Jhering, Geist des römischen Rechts, Bd. 1, Zweite Auflage, Leipzig: Breitkopf und Härtel 1866, p. 14.

68 'Sodann kann aber dieser Zustand auch bei Sachen vorkommen, die sich zur Zeit noch im Eigenthum einer Person befinden, während das Eigenthumsrecht einer andern Person oder ein jus in re, z.B. das Pfandrecht, in der Bildung begriffen ist. Die Gebundenheit, wodurch hier das zukünftige Recht sich dem gegenwärtigen fühlbar macht, besteht selbstverständlich nicht darin, dass es dasselbe schlechthin lahm legt, sondern dass es dasselbe nur so weit beschränkt, als die Rücksicht auf seine eigene Entstehung dies nöthig macht. Beide: das gegenwärtige und zukünftige Recht vertragen sich ebenso gut mit einander wie das Eigenthum und ein jus in re; es handelt sich hier wie dort nicht um eine Aufhebung, sondern um eine Beschränkung des Eigenthums; dem Eigenthümer ist die Macht entzogen, die künftige Entstehung des Rechts durch Veräußerung zu vereiteln oder den Inhalt desselben durch Bestellung dinglicher Rechte zu verkürzen, während er im Übrigen im ungeschmälerten Genuss seines Rechts verbleibt.', Jhering 1871, p. 535.

69 Jhering 1871, p. 534-535. 


\section{REEHUIS}

\section{The 'legal bond' of the asset applied on the transfer subject to a suspensive condition in Dutch law}

In Dutch legal literature, it is accepted that the fulfilment of the condition has proprietary effect. ${ }^{70}$ The proprietary effect ensures that the transferee will become owner by operation of law if the condition is fulfilled and prevents that the transferor could frustrate the transfer of the assets by disposing the asset to a third party before the fulfilment of the condition. ${ }^{71}$ It also effectuates the transfer if the condition is fulfilled after the transferor has been declared bankrupt. Although it is accepted that the fulfilment of the condition has proprietary effect, there is no consensus on the explanation of this proprietary effect. It should be noted that, in contrast to the law valid before 1992, it is not possible to invoke any retroactive effect attached to the suspensive condition. Art. 3:38 sub 2 BW (the Dutch Civil Code) excludes such retroactivity. ${ }^{72}$ In Dutch legal literature, there are several more or less suitable alternative explanations for the proprietary effect. ${ }^{73}$ However, I want to focus on whether

70 Verheul, Eigendomsvoorbehoud (diss. Groningen), Deventer: Wolters Kluwer 2017, Chapter 4.2; Snijders \& Rank-Berenschot, Goederenrecht (SBR 2), Deventer: Wolters Kluwer 2017/489; Stolz, De voorwaarde in het vermogensrecht (diss. Leiden), Boom Juridische Uitgevers: Den Haag 2015, p. 905 ff.; Bartels \& Van Mierlo, Mr. C. Asser's Handleiding tot de beoefening van het Nederlands burgerlijk recht. 3. Vermogensrecht algemeen. Deel IV. Algemeen goederenrecht, Deventer: Kluwer 2013/243; Reehuis, Monografieёn BW B6c. Eigendomsvoorbehoud, Deventer: Kluwer 2013/20; Reehuis \& Heisterkamp, with contributions by Van Maanen \& De Jong, Pitlo. Het Nederlands burgerlijk recht. Part 3. Goederenrecht, Deventer: Kluwer 2012/122; Reehuis, Monografiën BW B6a. Overdracht, Deventer: Kluwer 2010, p. 85-98.; Peter, Levering van roerende zaken, Deventer: Kluwer 2007, p. 132 and 141; Scheltema, De goederenrechtelijke werking van de ontbindende voorwaarde (diss. Leiden), Deventer: Kluwer 2003, p. 348 ff.; Kortmann, 'Eigendom onder voorwaarde', in: E.H. Hondius et al., Quod Licet (Kleijn-bundel), Deventer: Kluwer 1992, p. 201-208; Vriesendorp, Het eigendomsvoorbehoud (diss. Groningen), Deventer: Kluwer 1985, p. 59; Mezas, Eigendomsvoorbehoud (diss. Nijmegen), Zwolle: W.E.J. Tjeenk Willink 1985 , p. 39.

71 In Dutch law, a third party, when he is in good faith, can become owner after all, via third-party protection (art. 3:86 BW for movable and art. 3:88 BW for immovable goods). Further protection may possibly be offered via art. 3:36 BW.

72 TM, Parl. Gesch Boek 6, p. 145; See also Snijders \& Rank-Berenschot, Goederenrecht (SBR 2), Deventer: Wolters Kluwer 2017/416; Stolz, De voorwaarde in het vermogensrecht (diss. Leiden), Boom Juridische Uitgevers: Den Haag 2015, p. 133 and 158 ff.; Bartels \& Van Mierlo, Mr. C. Asser's Handleiding tot de beoefening van het Nederlands burgerlijk recht. 3. Vermogensrecht algemeen. Deel IV. Algemeen goederenrecht, Deventer: Kluwer 2013/244; Reehuis \& Heisterkamp, with contributions by Van Maanen \& De Jong, Pitlo. Het Nederlands burgerlijk recht. Deel 3. Goederenrecht, Deventer: Kluwer 2012/121 ff.; Scheltema, De goederenrechtelijke werking van de ontbindende voorwaarde (thesis Leiden), Deventer: Kluwer 2003, p. 304.

73 There are, for example, writers who believe in the doctrine of division, in which it is assumed that the transfer subject to a suspensive condition of an asset divides the right of ownership into a right of ownership subject to a resolutive condition and a right of ownership subject to a suspensive condition. Other authors considers that the acquirer already has a right, although it's not a right of ownership but rather what is called 'Anwartschaftsrecht' in Germany. There are also writers who assume that the acquirer does not have a right yet, but an expectation which is protected by proprietary effect of the fulfillment of the condition. The discussion about the explanation of the proprietary effect of the fulfillment of the 


\section{ON JHERING'S PASSIVE WIRKUNGEN}

Jhering's theory on the 'legal bond' of the asset is insightful for the explanation of the proprietary effect of the fulfilment of the condition in Dutch law.

In today's Dutch law, using art. 3:38 BW, parties can transfer assets conditionally by delivering the assets pursuant an obligation to transfer under a condition precedent (art. 3:38 sub 1 jo. 3:84 sub 1 jo. lid $4 \mathrm{BW}){ }^{74}$ When agreeing to a transfer subject to a suspensive condition, parties aim, on the one hand, to postpone the transfer of the assets until the agreed condition is fulfilled and, on the other hand, to ensure that the transfer of the assets will take place if the condition is met. ${ }^{75}$ The doctrine of the 'legal bond' of the asset fits in well with what parties who make a transfer subject to a suspensive condition have in mind. Suppose that A transfers assets to B under a suspensive condition. Although the transfer as an act has already taken place whereas the transfer of the assets as a result is postponed until the condition is fulfilled, the 'legal bond' of the asset secures that the transfer of the assets will take place if the condition is met. According to Jhering's theory, A has not just bound himself, but also the assets. Therefore, the assets are 'legally bound' in the sense that they will only transfer to B if that condition is met. A is entitled to the asset as long as the condition remains unfulfilled. Suppose that shortly after A transfers assets under a suspensive condition to $\mathrm{B}, \mathrm{A}$ transfers the assets yet again, but now to $\mathrm{C}$. Dispositions that A carries out pending the condition do not influence the fact that the $\mathrm{B}$ will become owner if the condition is fulfilled - apart from the possible application of rules with regard to thirdparty protection. Because of the transfer subject to a suspensive condition, the assets were already 'legally bound', which means that A is limited in his control over the assets. He can only hand over the assets to $\mathrm{C}$ under the burden of that 'legal bond'. $\mathrm{C}$ receives the assets under the same 'legal bond', that is, that the assets will be transferred as soon as the condition is fulfilled. The bankruptcy of A or C pending the condition will not stop B from obtaining the assets if the condition is fulfilled. The assets were already 'legally bound' through the transfer subject to a suspensive condition before the bankruptcy, and so they transfers when the condition is realised.

condition is very much alive because of a recent ruling of the Dutch Supreme Court. The Supreme Court handed down a judgement (HR 3 June 2016, ECLI:NL:HR:2016:1046, NJ 2016/290 Rabobank/Reuser) that involved the transfer subject to a suspensive condition in the context of a retention of title clause. Some writers consider this judgement as a confirmation of the doctrine of division. Without going into detail, I don't think that's necessarily the case.

74 In the Dutch Civil Code (BW) all assets can be transferred subject to a suspensive condition (based on art. 3:38 jo. 3:84 BW). These assets can be choses (zaken), shares, debts, and limited real rights. In addition, through the use of art. 3:98 BW, a suspensive condition can also be bound to the establishment of limited real rights.

75 See also: Verheul, Eigendomsvoorbehoud (diss. Groningen), Deventer: Wolters Kluwer 2017, chapter 4.2; TM, Parl. Gesch. Boek 3, p. 185. 


\section{Conclusion}

The proprietary effect of the fulfilment of the suspensive condition in a conditional transfer is traditionally explained by the retroactive effect of the fulfilment of the condition. In the nineteenth century, various writers wondered whether this explanation was satisfactory. Jhering proposes a different theory for the explanation of the proprietary effect of the fulfilment of the condition. In his article 'Passive Wirkungen der Rechte', he creates a theory based on Roman law in which the proprietary effect is explained by the passive Wirkungen of the 'legal bond' of the asset. In his theory, the fulfilment of the suspensive condition has a proprietary effect without using retroactive effect of the fulfilment of the condition. Despite the fact that the transfer of rights is postponed until the condition is realised, the asset is already 'legally bound' because of the conditional transfer. This ensures that the ownership is transferred if the suspensive condition is fulfilled.

Jhering's theory is insightful for Dutch law because the Dutch Civil Code excludes retroactive effect of the fulfilment of the condition. The doctrine of the 'legal bond' of the asset also corresponds with the intention of the transfer in the case of a suspensive condition. It fits within the Dutch system of property law and explains in a simple manner the proprietary effect of the fulfilment of the condition.

H.B. Reehuis ${ }^{76}$

Groningen

76 Hermen Reehuis is PhD-student at the Legal History department, University of Groningen 